\title{
DOCUMENTED MEMORIES OF RICHARD MOKO'S LIFE AND CONTRIBUTION: A SEVENTH-DAY ADVENTIST HERITAGE REFLECTION
}

\section{Mxolisi Michael Sokupa}

Stellenbosch University

sokupam@hbc.ac.za

\section{ABSTRACT}

The celebration of leaders has not been in the centre stage of Seventh-day Adventist practice. There are several reasons for this: the fear of this getting out of hand, leading to the veneration of human leaders; the contested histories and memories of leaders; and a need to create a distance between the dead and the living. This article reflects on the documented memory of contribution of a Seventh-day Adventist South African pioneer, Richard Moko.

Keywords: Richard Moko; Seventh-day Adventist; documented memories; missionary; ordained minister; Adventist heritage

\section{INTRODUCTION}

Documenting the history of the Seventh-day Adventist Church in South Africa has become important, especially in the past two decades that have seen rapid changes in its structure and demographics. With the dawn of the new democratic South

\section{UNISA $\cong$}


Africa in 1994, the Seventh-day Adventist Church accelerated the transformation of its structures from a racially divided polity to a structurally united one, a process that started in the early 1980s. Du Preez $(2010,99)$ observes that 'the SDA Church had to be systematized within a political context that was in a state of flux, with colonial, national, racial, cultural and language considerations impacting upon the direction that policies and politics were taking'. The scarcity of people with memories of the pioneers of the Seventh-day Adventist Church in South Africa has created immense gaps in the history of the church. The few documented memories have therefore become even more important to the Seventh-day Adventist Church that has gone through a series of organisational changes. We have on record that the first black South African to be ordained by the Presbyterian Church was Tiyo Soga on 12 August 1871 (Tiyo Soga, 2015) Forty four years later, in 1915, Moko, the first black Seventh-day Adventist pastor in South Africa, was ordained. The year 2015, therefore, marks a centennial of Moko's ordination into the gospel ministry within the Seventh-day Adventist Church. This article examines the documents that record memories and contributions of Moko, or lack thereof.

There are a number of historically significant centennials that have come up in the past few decades. One of these is the centennial of the death of one of the founding members of the Seventh-day Adventist Church, Ellen G. White, on 16 July 1915. The centennial of Ellen G. White's death was celebrated by publishing a collection of her letters that have been preserved for more than a century. Therefore, celebrating a church pioneer in this fashion has opened up a number of possibilities for heritage reflection within the Seventh-day Adventist Church. Along a similar vein, this article seeks to highlight an important centennial event that marks the official recognition of the first black minister of the Seventh-day Adventist Church.

In this paper, I hope to highlight some relevant documents that have recorded memories of Moko's life and contribution. I will also look at the historical background that may place those memories and documents in context. Most importantly, to draw from the memories of courage, determination and commitment, a historical documentary monument that will inspire future generations to reach such levels of commitment to the gospel ministry. The key question is: Has Moko's life contribution been adequately documented in Seventh-day Adventist historiography? To answer this question we have to examine available documents on Moko and on Seventh-day Adventist history in general. Another important question that deserves attention is: Have Seventh-day Adventist historians been sensitive to the importance of Moko's contribution to the development of the Seventh-day Adventist Church? 


\section{A BRIEF BACKGROUND OF THE SEVENTH-DAY ADVENTIST CHURCH}

The history of the Seventh-day Adventist Church in South Africa may be traced as far back as 1878, with William Hunt coming to South Africa and managing to convince several people, including J.H.G. Wilson, who was a Methodist preacher at the time (Seventh-day Adventist [SDA] Encyclopaedia 1996, 630). The Seventhday Adventist mission in South Africa started under the leadership of American missionaries, C.L. Boyd and D.A. Robinson, who arrived in Kimberley in July 1887 (SDA Encyclopaedia 1996, 631). They were commissioned by the General Conference of Seventh-day Adventists in response to a call by interested prospective members, Pieter Wessels and George van Druten. From the early beginnings in Kimberley, the Seventh-day Adventist Church began to spread from Kimberley to Cape Town and later even beyond the South African geographical boundaries of that time. In 1893 Moko was introduced to the Seventh-day Adventist Church and became the first African convert (SDA Encyclopaedia 1996, 632). The Seventh-day Adventist Encyclopaedia, which is the official source of Seventh-day Adventist history and teachings, fails to give a contextual account of the life of Moko. It is hoped that as this source is undergoing major revision currently (2016-2020) it will reflect a contextual account of the life of Moko and many other leaders. The next section gives a brief biography of Moko.

\section{MEMORIES OF RICHARD MOKO'S LIFE: A BRIEF BIOGRAPHY}

Richard Moko was born near Grahamstown in 1850. According to Hlanga Mafani, he was a descendent from a long line of AmaXhosa chiefs. His wife's name was Emily. They had six children: Boyce, Grace, Elizabeth, Paul, Richard (junior) and Ellen (Mafani 2011, 107). Moko had the gift of languages; he could read and write English and Dutch (Helderberg College Archives, Heritage Record number HR4, Moko Collection). Mrs E. Hepburn (quoted in Cooks 1986) recalls the story of Moko's conversion as he related it to her: 'Richard had a store in Port Elizabeth but it was not doing well, hence he decided to sell the store and go to Rhodesia.' Back in those days the railway line ended in Johannesburg. He had to walk to Rhodesia. He ended up in Cape Town without reaching Rhodesia, because of a voice that insisted that he turn around and go to Cape Town. This marked Moko's conversion (Cooks 1986, 4). It may be noted that the story of Moko's conversion is side-lined by historians, probably to avoid dealing with the nature of divine communication. Those who recorded the story were drawing not from secondary sources; E. Hepburn claims to have had a direct narration from Moko himself. This leads to a conclusion that there has been a sifting and filtering of historical data in later years. This was 
done to avoid explaining divine communication and also due to the once-off nature of the encounter or phenomenon.

Mafani (2011) has it that Moko was converted in 1895 and baptised later. Van Zyl $(1990,28)$ places his conversion in 1893 and his baptism in 1895. This article supports the latter because there is a chronological order of events in the life of Moko that are documented. Cooks (1986) records the story from Mrs Hepburn that, after Moko's conversion, there was a period of two years in which he undertook an intensive study of the Seventh-day Adventist beliefs (Cooks 1986, 4). Therefore, 1893 and 1895 could make sense, although this version throws out the Jameson's raid of 1895 that has Moko come to Johannesburg after turning back from his journey on foot to Rhodesia. He finds the station full of soldiers and he is pushed into the train to Cape Town. There are other possibilities to support 1893; such as the Matabele land revolt by Lobengula. The soldiers that were deployed for this operation may have been coming back in 1893. This brings another possible scenario.

Moko was given a good offer by Lord Roberts to be his interpreter, but he never accepted the offer. 'He refused in case he would be asked to do or say something his conscience would not permit' (Helderberg College Archives HR 4, Moko Collection). Moko joined George Shone and I.B. Burton in mission work among the Xhosa people. In 1908 they went searching for a mission site. They were travelling on a wagon they called the gospel wagon. Charles Sparrow heard of their search and offered 520 acres for what would later be called Maranatha Mission. Moko's involvement in the early establishment of Seventh-day Adventist mission stations has not been adequately recognised in Seventh-day Adventist historiography. One finds that Sparrow, who gave land, has been given more recognition than those who were involved in envisioning a mission statement and working towards its establishment. Nhlapo (2012) in his book highlights the contribution of Moko. He states:

Alongside his missionary partner, G.W. Shone, he travelled widely through the country in a small wagon, holding meetings and establishing churches. The two had been together since 1803[1903] in East London and now, working as one, they worked for, and helped locate, the site for Maranatha Mission in Grahamstown under the supervision of the president of the South African Union Conference, W.S. Hyatt, and missionary W.S. Tarr. (Nhlapo 2012, 15)

Moko is remembered by a scholar outside the Seventh-day Adventist community of faith, Dr Keith Tankard. Tankard (1994) gives Moko the title 'Missionary' which was not given to him by his contemporaries. Locals in the Seventh-day Adventist system at the time were never given that title.

Moko later settled in East Bank Location, East London. He worked among coloured people. It is interesting to note how his preaching was rejected because he pointed to Saturday as the day of worship. This escalated to the point where the matter was brought before the magistrate. Tankard, a retired history professor from Rhodes University, observes that Moko arrived in East Bank in October 1903. Within six months there was a petition to the Location Superintendent that Moko 
was preaching heresy, 'making believers accept that Saturday was the Sabbath day instead of Sunday' which, the petitioners pointed out, was a Jewish custom. He was persuading the 'younger sex' to stay away from work on Saturdays, which the petitioners claimed was 'causing discontent' amongst their families (Tankard 1994). Tankard, argues further that Moko was warned and eventually expelled from the village on grounds that he misconstrued section 13 of Act 11 of 1895 . The provision of this Act under the heading 'Procedure against persons unlawfully in location', was used against Moko, who was a fully registered resident in the location. Tankard, further observes:

...the seriousness in which Moko's preaching was viewed can be seen from the testimony which Superintendent Lloyd delivered before the Lagden Commission earlier that very year. He had testified that he believed the locations existed purely to supply labour and that wages to the Black people should be held at such levels as to force them to work. East Londoners, he said, tended to pay "extravagant wages" which enable a man to work only a few days a week and "to lie idle at home" for the rest of the time. He personally put a stop to that, he boasted, never allowing a man to absent himself from work for more than one or two days a week without serving an eviction order on him. His "general view", he told the Commission, was that it was "not reasonable for an African to rest every Saturday". (Tankard 1994)

Tankard concludes that in Superintendent Lloyd's eyes, 'Reverend Moko was preaching sedition and therefore had to go. He was quite willing to expel the evangelist at the very first hint of the content of his preaching in October 1903'. The allegations brought before him were therefore not investigated fairly, hence Lloyd was prepared to act upon them as fact and Moko was expelled from the location (Tankard 1994).

Regarding Moko's experience in East London, Pastor J.E. Symons (quoted in Cooks 1986) wrote of pastor Moko:

Old Brother Richard Moko was a wonderful man. He once told me of an experience that he had while holding open-air meetings in East London Location. Someone rushed at him and forcefully knocked out two of his teeth. It was near the spot that our first church building was erected for Africans, in East London. Brother Moko said that he would gladly lose every tooth he had if it meant just so many churches being raised up to the glory of God. (Cooks $1986,4)$

This article, in line with Tankard's argument, takes the position that the content of Moko's teaching, the Sabbath doctrine among others, was not the main cause of his expulsion. This is buttressed by the fact that there are a number of Sabbatarian groups that established their missions among the AmaXhosa without facing the reaction that Moko faced in East London. 


\section{EVIDENCE OF OTHER SABBATARIAN GROUPS}

It appears that Moko's case was an isolated one, as clearly analysed by Tankard (1994). There is evidence that there were other Sabbatarian groups in South Africa at the time. The attempt by Mafani $(2011,119)$ to show that the Sabbath doctrine was introduced by Moko in the Cape, is not supported by strong arguments. He cites $\mathrm{Mr}$ Sehare, who in his view came later. However, the dating of the introduction of the Sabbath doctrine in the Cape is arguably earlier to Moko's ministry in the Cape, as presented by Pauw (1975).

Pauw (1975) observes that several new arrivals in the mission field came to be established among AmaXhosa before 1900. Among these there was the South African Baptist Missionary Society that was formed in 1892. The South African General Mission Station and the Salvation Army also began working before 1900 (Pauw 1975, 26). The Seventh-day Adventist Church mission is also mentioned, along with a number of smaller missions that opened work among the Xhosa early in the twentieth century. The Seventh-day Adventists mission work was opened in several centres, while the Free Methodist Church of North America and the Pilgrim Holiness Mission were more localised in certain areas (Pauw 1975, 27).

The missions that had a Sabbatarian belief and practices were also growing during the turn of the nineteenth century. Pauw (1975) notes that one of the early Negro Baptist missionaries, Albert Christian, after having worked in the Port ElizabethUitenhage area for some time, returned to America in 1902. There he joined the Church of God and Saints of Christ founded by the 'Prophet' William S. Crowdy in 1896. Some of the teachings and beliefs held by this church (adult baptism by immersion and observance of the seventh day as Sabbath) were combined with the belief that the Negroes were descended from the ten lost tribes of Israel (the members called themselves 'Israelites') and with the revival of diverse Old Testament usages. Christian returned to the Eastern Cape in 1903, continued mission work with his new faith and after his death was succeeded in 1906 by a local leader, John Masikinya (Pauw 1975, 29).

Pauw (1975) traces the beginning of another cluster of independent SabbatarianBaptist groups from W.W. Oliphant, who became active as church leader about 1906. These groups are identified by variations of the name Seventh Day Baptist Church of Christ, the best known being the (Bantu) Church of Christ, which gained prominence under Bishop James Limba. Whether Oliphant had any formal connection with the Negro missionaries is not certain, but there is evidence that he was at one stage in correspondence with a Seventh Day Baptist Church in America (Pauw 1975, 30). According to Mqotsi and Mkele (1946, 107), Oliphant tried to convert a Sabbatarian group, the Israelites, but was influenced by them instead. When he returned to his Church in 1914 he was excommunicated from the movement he had started because of his Israelite views. He then formed the Baptist Church of the Seventh-day Adventists of Africa. 
Another mission that is associated with Sabbatarianism is the Church of Christ Mission. According to Taylor $(1928,298)$ this movement was started in 1920 in Kimberley by Kalane. Kalane was a South African who had visited America, was sent back by an American group to conduct work on their behalf, and succeeded a Rev. Payne. Gerdener $(1958,115)$ traces the movement to have started on the Rand in 1906, adding that Thomas Kalane started work in Kimberley in 1920 after a visit to America, where funds were obtained for the work he proposed to do. Since the government required that the work be supervised by a white missionary, the Rev. O.E. Payne was sent from America, arriving in Kimberley in 1923 (Pauw 1975, 30). Hofmeyr and Pillay (1994) give a balanced account of the history of Christianity in South Africa in terms of covering political as well as religious developments. For example, major socio-political events are placed side-by-side to ecclesiastical events covering various periods of the history of the Christian church in South Africa (Hofmeyr and Pillay 1994, 245). While Moko lived and died before the policies of apartheid were legalised in South Africa, there is clear evidence of racial segregation long before the legalisation of apartheid. However, these developments seem to have marginalised the Sabbatarian groups. All the names given above do not appear in Hofmeyr and Pillay (1994). This omission is an indication of the attitudes of the so-called 'mainline churches' towards smaller denominations. The Seventh-day Adventist Church, at the time of the publication of this volume, was already close to 100000 in membership in South Africa, and about 14 million world-wide.

\section{MOKO'S MINISTRY AND ORDINATION IN CONTEXT}

Elphick (1997) observes that from the year 1911, the relationship between missionaries and African Christians was not at its best. He notes that generally, most Protestant mission strategists prioritised educating and ordaining young men as ministers and leaving them to care for churches on their own. 'Yet in South Africa the missionaries were reluctant to ordain blacks, even the most successful evangelist. They believed that blacks were incapable, as yet, of the demanding task of a pastor - managing money, rebuking sin, and administering complex organisations' (Elphick 1997, 350). The developments that came in the late nineteenth century are summarised as follows:

Under pressure from their home boards, missionaries did ordain Africans from the late nineteenth century, but by 1911, after more than a century of mission activity, only 401 ordained Africans (compared to 649 ordained missionaries) were ministering in missionrelated churches in South Africa. Missionaries often refused to treat the African clergy as their professional equals and brothers in Christ. Consequently many Africans, embittered by their treatment as second-class ministers, quarrelled with the missionaries over money, status, and authority - few of these squabbles concerned Christian doctrine or disagreements over principles of church governance. (Elphick 1997, 350) 
It is against this historical background that we need to see Moko coming through as an ordained pastor of the Seventh-day Adventist Church. However, there is no evidence of any pressure or tension between Moko and the missionaries that were closely associated with him.

The missionaries would need the close collaboration of African Christians, who comprised most of the missions' evangelists and teachers, and many of their pastors. Of all the nonmenial employees of Protestant missions, 85 per cent were black in 1911 (95 per cent in a well-established mission such as the American Board). Protestant mission strategists in the nineteenth century had firmly believed that missionaries in a new field should rapidly educate and ordain young men as ministers, then leave them to manage their own 'native church'. (Elphick 1997, 349-350)

The tension between foreign and indigenous missionaries is clearly demonstrated in the late nineteenth century. Elphick (1997) connects it to the Ethiopian secession and describes it as follows:

The frustrations of the black clergy erupted most dramatically in the Ethiopian secessions, which in the 1880s and 1890s engulfed most Protestant missions (see chap. 12, passim). The missionaries in turn felt betrayed by their African colleagues, whose grievances they only vaguely comprehended, and feared the loss of missionary control over the entire Benevolent Empire. Yet most black clergy declined to join the separatist Ethiopian movement and remained - many, no doubt, reluctantly and warily - in the missionary churches. Moreover, some Ethiopians, later returned to their former missions, or joined other mission-related churches. (Elphick 1997, 350)

The various churches responded in different ways to this tension. The American Board and the Scottish Presbyterians created separate African churches under African leadership, but with close ties to the missions. On the other hand, the Anglicans took a different approach by integrating black and white ministers and missionaries within the same diocesan structure. In addition to this integration at diocesan level, they also granted African clergy participation in the Provincial Missionary Council, where important decisions were taken.

Still, the more perceptive among the missionaries concluded that new arrangements had to be devised to accommodate the aspirations of African moderates while maintaining, at least temporarily, a measure of missionary oversight. The American Board and the Scottish Presbyterians created separate African churches under African leadership, but with close ties to the missions. The Anglicans integrated white and black within the same diocesan structure, and granted African clergy considerable voice in the Provincial Missionary Council, where resolutions on social issues were often considered. Missionaries slowly withdrew from parish or congregational management, where the likelihood of conflict with African clergy was most acute, and moved instead into specialised fields like education and medicine, into the growing ecclesiastical bureaucracies, and into social and political 
activism. The transition was slowest in the German Lutheran and some of the recently formed Anglo-Saxon missions, and fastest in the older Anglo-Saxon missions such as the London Missionary society, the Anglicans, the Scots, the American Board, and the Methodists. Between 1911 and 1938 black pastors outnumbered ordained missionaries by a ratio of 2.1 to 1 .

The issues that affected different denominations at the height of Moko's ministry also affected the Seventh-day Adventist Church. The Seventh-day Adventist Church was not insulated from the challenges that led to black ministers not receiving the honour they deserved. The next section focuses on Moko's experience and documented memories of his ministerial calling.

\section{DOCUMENTED MEMORIES OF RICHARD MOKO'S MINISTRY}

An evaluation of the documented memories of Moko is now apt. The Seventh-day Adventist historiography generally does not seem to place Moko in a position where his contribution is recognised and remembered by people who read about Seventhday Adventism in South Africa. Below, Seventh-day Adventist historians are listed and the omission or recognition of Moko's contribution is noted.

Spalding lists early African leaders, who were involved in teaching and evangelism: David Kalaka, Richard Moko, James Malinki, Isaac Xiba, James Moyo and John Ncube. The Maranatha Mission was established in 1904 by Moko. Spalding presents him as a well-educated native minister (Spalding, 1962).

Robinson (n.d.) records that around 1895 Moko was living in the Kimberley area, unaware of the Seventh-day Adventists. Elder Haskel was holding meetings in a hall in Beaconsfield. Moko 'paused to listen for a few minutes, his interest was aroused, he went in, and listened to the rest of the discourse. He continued to return until he was won and had been baptized'. Robinson presents Moko as 'our most faithful and valiant stand bearer' and as 'the first African to be ordained to the ministry' (Robinson n.d., 35).

According to Swanepoel (1972), Moko was introduced to the Seventh-day Adventist faith for the first time in Kimberley around 1895. He writes:

Later in the year Robinson and Haskel visited the Diamond Fields. Haskel conducted special meetings in the church for about ten days, one in the early morning before people went to their work, and one in the evening, each day. On Saturday afternoon a meeting was in progress, when a Xhosa man, living in Kimberley, stepped into the church to listen to the sermon. This was Mr R. Moko, a teacher. He showed great interest, and after the meeting he was taken to the home of one of the members who taught him more of the Seventh-day Adventist beliefs. He and his wife joined Beaconsfield congregation, and he later became a minister of the church, working extensively for the Xhosa people. (Swanepoel 1972, 55-56) 
Swanepoel (1972) also describes Moko's ministry and work around the Kimberley area:

During July [1897], Moko and Rogers had begun work among the African people living in the Kimberley vicinity. They conducted evangelistic meetings and a Bible School certain evenings of the week, but Olsen's Institute was a much more intensive programme for reaching the African people. Classes were held daily - both before the regular work started and in the late afternoon and evening. There were about a dozen men that attended regularly, and by the end of the institute, four of them were baptized and received into membership of the church. These were, Messrs D. Kalaka, J Riley, Nero and C. Felis. Shortly after the institute the book Steps to Christ, by Ellen G. White, was due to be published in both Xhosa and Sesotho, and was to be used as the basis for mission-work by these men among their own people. (Swanepoel 1972, 59)

Thompson writes concerning the third Adventist Church that was established in 1890, at Rokeby Park about eighteen miles from Grahamstown (Thompson 1977, 72). He acknowledges D.F. Tarr as the first national English-speaking Adventist in South Africa. He also mentions Tarr in his account of the development of the Seventh-day Adventist mission among the Xhosa people. He gives credit to him for the location of Bethel Mission in Butterworth and the Cancele Mission near Mount Frere. According to Thompson, Sparrow was instrumental in developing interest among the Xhosa leading to the establishment of the Maranatha Mission located in Fraser's Camp near Grahamstown, which came before Bethel and Cancele (Thompson 1977, 72-73). Thompson does not make any mention of Moko and his connection with the Sparrows and the Tarrs in the establishment of Seventh-day Adventist missions.

Pantelone's (1996) work deals with the development of Seventh-day Adventist mission in South Africa. He traces the development of the Seventh-day Adventist Church in the Eastern Cape from an encounter between Wessels and Tarr from 1887. As a result of the work of Ira J. Hankins, a Seventh-day Adventist Church was established in 1889 at Rokeby Park. By 1891 the Seventh-day Adventist Church had extended up to Cathcart district with D.F. Tarr and later his brothers, Walter and James Tarr and their families (Pantelone 1996, 51).

From the accounts of Seventh-day Adventist history outlined above, it seems that Moko's contribution was not presented fairly. Seventh-day Adventist historiography was started by white Seventh-day Adventist historians. This imbalance is reflecting the time of apartheid in which Moko and other black leaders were forgotten or pushed to the background. In the section below I quote from a source that no historian has quoted before. This demonstrates the need to still dig for sources of a primary nature where these early pioneers themselves are writing and giving mission reports. 


\section{MISSION LEADERSHIP REPORTS FROM MOKO}

There are quite a number of reports from Moko's own pen. He reports from Herschel (Moko 1914b):

A few weeks ago I was at my home in Debe Nek, and held a very good meeting on Sabbath in the building I erected near my home. We had a goodly number present, among whom were quite a number of students of Maranatha Mission School who were home for their winter holidays. It pleased me very much to note the spiritual interest these students took in meeting and to hear their testimonies. I praise God for what He is doing through our missionaries for these dear youth who were once in spiritual darkness. Brethren we ought to uphold these workers in lonely places by our earnest prayers.

Moko played an important role in the development of the Maranatha Mission School. He expresses a deep-seated burden for the young people he met from that school. It seems that he had a larger interest of the mission at heart than just the location where he was assigned at the time.

In terms of race relations there seems to be a hint in this report on how Moko interacted with his fellow missionaries and ministers. He writes:

On the $5^{\text {th }}$ of this month I arrived at Brother Cloete's farm, near Lady Grey. The evening I arrived I was not well, and my good white brother gave me some treatment which made me feel quite better. I did not expect it at all; I thank God that I have such kind white brothers. (Moko 1914a, 3)

Moko reports again:

Since my last report, the Lord's blessing has been attending my work among the natives here. I sold a few 'Steps to Christ' and some tracts on the Sabbath and the Second Advent; these books did their work well and opened the way for me to hold many Bible readings. Some have begun to obey the truth, while others are interested. The first to keep the Sabbath received a hard beating from her husband, and was sent to her parents. The latter brought her back and a council was held, with the result that the woman was allowed to keep the Sabbath. Four others soon decided to take their stand for the truth. (Moko 1914a, 3)

\section{INTERVIEW WITH FELIX LUNGILE MOKO, A GRANDSON OF RICHARD MOKO}

Mr Lungile Moko (Moko interview, June 2013) reported that Richard Moko was the only one in the Seventh-day Adventist faith from his family. He expresses the family memories of Richard Moko as someone who was committed to the teaching of the Bible. Pastor Moko left a legacy with his family that any rituals that had to do with the dead, should be avoided. Most of the family members have kept the legacy faithfully. It is interesting to note that there is no grave stone for Pastor and Mrs Moko. Mrs Moko's grave is in Debe Nek at their home. Pastor Moko's grave is 
unidentified due to the forced removals in East London where he was buried. During the interview I asked if the family would consider a memorial stone where Moko's grave supposedly was, and Mr Lungile Moko's response was that they even tried to exhume the body without success. Therefore they have put that matter to rest. There is no visible memory of Richard Moko in terms of a grave or memorial stone.

\section{CONCLUSION}

This article has argued that there is a trail of documented memory of Richard Moko, but this memory seems to be filtered by the apartheid era in which most Seventh-day Adventist historiography originates. As a result of the late written accounts, some important primary sources are forgotten. A number of African writers have risen to the occasion by giving an account of the history of the Seventh-day Adventist Church from an African perspective. This has led to a re-membering of Moko's contribution. The life and work of Moko models a kind of commitment and determination that is needed in mission work. Although he faced fierce opposition in East London East Bank it is evident from the facts that have been highlighted that this had nothing to do with his method or approach. It is interesting to note how he presents his approach in his report on the work in Herschel. He started with spreading literature and then Bible readings and people made decisions based on conviction. His story should continue to be a source of encouragement to ministers and missionaries. The documented memories of Richard Moko reveal that there were earlier writers who acknowledged his work and contribution. Later there were historians who marginalised him and there has been a renewed interest in research on Moko and his contribution from about 2010. The Seventh-day Adventist Church has a number of pioneers who have not been acknowledged. A lot more research is needed to redress this problem.

\section{REFERENCES}

Cooks, J.B. 1986. 'Richard Moko, first indigenous minister of our church in South Africa,' South African Union Lantern, October 1.

Du Preez, G. 2010. A history of the organizational development of the Seventh-day Adventist Church amongst the coloured community in South Africa 1887-1997. Dissertation, University of the Western Cape.

Elphick, R. 1997. 'The benevolent and the social gospel: Missionaries and South African Christians in the age of segregation.' In Christianity in South Africa. James Currey: Oxford.

Gerdener, G.B.A. 1958 .Recent developments in the South African mission field. Cape Town: N.G. Kerk-uitgewers.

Helderberg College Archives, Moko Collection.

Hofmeyr, J.W. and Pillay, G.J. (Eds). 1994. A history of Christianity in South Africa, Vol. 1. Pretoria: HAUM Tertiary.

Mafani, H. 2011. From Genesis to germination. Self-published by Hlanga Mafani. 
Moko, Felix Lungile. Interview, Debe Nek, June 2013.

Moko, Richard.1914a. 'The native work,' South African Missionary, XIII(30): 20 July.

Moko, Richard. 1914b. 'Hershel location,' South African Missionary, XIII(38): 14 September.

Mqotsi, L. and Mkele, N. 1946. 'A Separatist Church: Ibandla Lika-Kristu,' African Studies, 5(2): 106-125.

Nhlapo, C. 2012. Tears of the black pulpit: A celebration of the legacy of black ministers in the north Bantu mission field from 1925-1965. Wandsbeck: Reach Publishers.

Pantelone, A. 1996. An appraisal of the development of Seventh-day Adventist Mission SA A missiological evaluation. Dissertation, University of Durban Westville.

Pauw, B.A. 1975. Christianity and Xhosa tradition. Cape Town: Oxford University Press.

Robinson, V. E. n.d. Third angel over Africa. Part 1. Unpublished, Helderberg College D7 325.

Seventh-day Adventist Encyclopedia. 1996. 'Richard Moko' Hagerstown, Washington D.C: Review and Herald Publishing Association.

Spalding, A. 1962. Origin and history of Seventh-day Adventists Vol. 4. Washington DC: Review and Herald Publishing Association.

Swanepoel, F. 1972. The origin and early history of the Seventh-day Adventist Church in South Africa, 1886-1920. Master's dissertation, Department of History, University of South Africa, Pretoria.

Tankard, K. 1994. 'Preaching the Word of God: The very strange case of the Reverend Moko,' Coelacanth, 32(2).

Taylor, J.D. 1928. Christianity and the natives of South Africa: A year-book of South African missions. Alice: Lovedale Institution Press, 298.

Thompson, R. 1977. A history of the growth and development of the Seventh-day Adventist Church in Southern Africa, 1920-1960. Dissertation, Rhodes University.

Tiyo Soga. 2015, August 5. Retrieved from www.sahistory.org.za/people/tiyo-soga

Van Zyl I.J. 1990. Lecture notes on church history, Part 5. Cape Town: ESDEA BOOKS. 